\title{
Tarihi Endüstri Yapıların Korunmasında Doğal Taşın Değiştirilmesi İçin Bir Değerlendirme Modeli: Kayseri Sümerbank Bez Fabrikası- Türkiye Örneği
}

\author{
Mehmet Cemal Acar ${ }^{1, *}$ \\ 1,* *Kayseri Üniversitesi, Teknik Bilimler MYO, İnşaat Bölümü, Kayseri, Türkiye, (ORCID: 0000-0002-3241-5353), acarc@kayseri.edu.tr
}

(İlk Geliş Tarihi 11 Temmuz 2021 ve Kabul Tarihi 15 Ekim 2021)

(DOI: $10.31590 /$ ejosat.969801)

ATIF/REFERENCE: Acar, M.C., (2021). Tarihi Endüstri Yapıların Korunmasında Doğal Taşın Değiştirilmesi İçin Bir Değerlendirme Modeli: Kayseri Sümerbank Bez Fabrikas1-Türkiye Örneği. European Journal of Science and Technology, (27), 950-960.

$\ddot{\mathbf{O} z}$

Restorasyon açısından tarihi taşların korunması önemlidir ancak yeni taşların kullanılmasını gerektirdiği durumlar da vardır. Tarihi yapıların duvarlarındaki taşların zarar görme derecesinin oldukça fazla olması veya özgün taşın tamamen yitiritilmesi gibi durumlarda bunların modernizasyonları, tadilatları ve yeniden inşalarına gerek duyulmaktadır. Bu restorasyon çalışmalarında, dayanım özelliği ve görünüm açısından anıtla uyumlu uygun taş kaynakları bulmak zorlu bir görevdir. Bu çalışma, tarihi yapıların duvarlarının onarımı için orijinal taşın değiştirilmesi olasılığını analiz etme ve değerlendirme yöntemini kapsar. Bu amaçla, erken cumhuriyet dönemine ait Türkiye'deki ilk endüstri yapılarından olan Kayseri Tarihi Sümerbank Bez Fabrikası'nda bir örnek uygulama çalışması yapıllmıştır. Bu makalede, Kayseri Tarihi Sümerbank Bez Fabrikası'nın Abdullah Gül Üniversitesi Sümer Kampüsü’ne dönüştürülmesi için hazırlanan restorasyon projesi kapsamında, fabrika duvarlarındaki tahrip olmuş taşların ve yerine kullanılabilecek yeni taşlar için dayanım, estetik ve uyumluluk değerlendirme ölçütünü sağlayan bir model oluşturulması amaçlanmıştır. Bu model, pahalı ve zaman alıcı analizlerin yapılmasını önleyecek, en az müdahale ile tarihi dokunun korunmasını sağlayacak ve gelecekteki malzeme kayıtlarına sahip olmayan restorasyon çalışmaları için de örnek olabilecektir. Bu çalışma, taşların seçiminde sadece estetik bir değerlendirme değil aynı zamanda onun, fiziksel ve mekanik özelliklerine göre taş seçimi yapılmasının önemini ortaya koyan bir model sunmaktadır.

Anahtar Kelimeler: Restorasyon, Taş, Sümerbank, Tarihi, Endüstri yapıları.

\section{An Evaluation Model for Replacing Natural Stone in The Conservation of Historical Industrial Buildings: A case study of Kayseri Sümerbank Bez Fabrikası-Turkey abstract}

\begin{abstract}
Conservation of historical stones is important for restoration, but there are cases where new stones are required to be used. In cases where the degree of damage to the stones on the walls of historical buildings is quite high or the original stone is completely lost, their modernization, modification and reconstruction are required. In the restoration work, it is a challenging task to find suitable stone resources that are compatible with the monument in terms of strength and appearance. This study covers the method of analyzing and evaluating the possibility of replacing the original stone for the repair of the walls of historical buildings. For this purpose, a case study was carried out in Kayseri Historical Sümerbank Cloth Factory, which is one of the first industrial structures in Turkey belonging to the early republican period. In this article, it is aimed to create a model that provides the strength, aesthetic and compatibility evaluation criteria for the destroyed stones on the factory walls and the new stones that can be used instead within the scope of the restoration project prepared to transform Kayseri Historical Sümerbank Cloth Factory into Abdullah Gül University Sümer Campus, This model will avoid expensive and time-consuming analyzes, preserve the historical texture with minimal intervention, and may set an example for future restoration works that do not have material records. This study presents not only an aesthetic evaluation in the selection of stones, but also a model that reveals the importance of choosing stones according to their physical and mechanical properties.
\end{abstract}

Keywords: Restoration, Stone, Sümerbank, Historical, Industrial buildings.

* Sorumlu Yazar: acarc@,kayseri.edu.tr 


\section{Giriş (Introduction)}

Çok eski tarihlerden günümüze kadar doğal taşlar yapılarda kullanılmaktadır. Kentin sosyal, kültürel, ekonomik oluşumuna etki etmiş tarihi yapıların duvarlarında kullanılan doğal yap1 taşlarını korumak tarihi miras açısından büyük önem taşımaktadır. Tarihi yapıların duvarlarındaki taşlarının parçalanması, çukurlaşması gibi zarar görme derecesinin oldukça fazla olması veya özgün malzemenin yitirilmesi durumunda taş değişimleri söz konusu olmaktadır. Geçmişten günümüze kadar pek çok araştırmacı bunun nedenleri ve çözüm yollarını üzerinde çalışmaktadır (Oakeshott, 1975; Přikryl, 2007; Török ve Přikryl, 2010; Sousa, 2014; Aldoasri vd., 2017; Martínez-Martínez vd., 2018; Gibeaux vd., 2018; Saba vd., 2019; Grazzini vd.,2020; Del vd., 2020; Salvatici vd., 2020; Çelik vd., 2021; Klimek vd., 2021; Aboubacar vd., 2021). Roma ve Doğu Roma İmparatorluğu (Bizans) dönemi yapılarında bazalt, mermer, kireçtaşı, traverten, volkanik tüfler; Anadolu Selçuklu Devleti yapılarında mermer, volkanik tüfler ve yumuşak kalkerler, andezit, bazalt; Osmanlı İmparatorluğu dönemi yapılarında ise traverten, mermer, kireçtaşı, serpantin ve granit taşı, Cumhuriyet döneminin ilk yıllarında yapılan kamu binalarında ise özellikle tüf taşları kullanılmıştır. Tarihi yapılarda kolay ulaşılabilir ve taşınabilir olmaları gibi ekonomik nedenlerle yerel tüf taşlar daha çok tercih edilmiştir. İstanbul'daki tarihi yapılarda kireçtaşı (yerel ismi küfeki taşı) ve Marmara mermeri yaygın olarak kullanılmıştır. Bakırköy, Sefaköy, Yeşilköy, Yenibosna ve Şirinevler'deki taş yataklarından çıkarılan, gözenekli ve kolay şekillendirilebilen kireçtaşı özellikle Bizans ve Osmanlı İmparatorluğu dönemlerinde İstanbul'daki tarihi yapıların birçoğunda ana yap1 malzemesi olarak tercih edilmiştir. Örneğin Ayasofya'nın (532537) dış duvar örgüsünde, Fatih Camii'nin (1463-1470) dış duvarlarında ve minaresinde, Süleymaniye Camii'nin (15501557) fil ayakları, dış duvar örgüsü ve harim bölümünün döşemelerinde kireçtaşı (küfeki taşı) kullanılmıştır (Serkan, 2010). Ankara'daki tarihi yapılarda kullanılan doğal taş ise Ankara taşı olarak da adlandırılan andezit tüfüdür. Pembe renkli, gözenekli ve cila tutmayan bir taş olan Ankara taşı birçok tarihi yapıda kullanılmıştır. Tüm doğal taşlarda, taşın yapısal özelliklerinin yanı sıra, insan ve doğa koşullarının olumsuz etkilerine maruz kalmaları sebebiyle, zaman içerisinde ayrışmaya maruz kalır. Bu olay, taşların yüzeysel bozulma ve ayrışmasına, daha sonrasında ise parçalanarak yitirilmesine yol açar (Oakeshott, 1975; Sousa, 2014; Aldoasri vd., 2017; Saba vd., 2019; Klimek vd., 2021). Buna en güzel örnek Oxford üniversitesi tarihi binaları gösterilebilir. Bu yapıların taş bloklarının hava kirliliğinden dolayı çürümesi sonucu özgün malzeme değiştirilmiştir. Yerine koyulan taşın uyumsuz seçilmesi ve işçilik hataları sonucu üniversite binaları yeteri derecede korunamamış ve Oxford üniversitesinin kurumsal imajına zarar vermiştir (Oakeshott, 1975). Tarihi yapıların yenileme çalışmalarında, öncelikle orijinal yapı malzemesi korunmaya çalışılır ancak duvarda aşırı bozulan ve ayrışan taş varsa, bu taş aynı ocaktan ve aynı özellikteki taş ile değiştirilmesi uygun olur. Böylece, duvarın dayanımı ve işlevselliği mümkün olduğunca korunmuş olur. Kullanılan orijinal taşın özellikleri hakkında çoğunlukla bilgi veya belgeye rastlanmaz. $\mathrm{Bu}$ nedenle, restorasyon yapılmadan önce binanın özgünlük ve karakterinin belirlenmesine ihtiyaç vardır. Orijinal ve muadil taşın kökeni, bugünkü durumu, mekanik ve fiziksel özellikleri çok iyi bilinmesi gerekir. Kullanılacak taş, mümkün olduğunca, fiziksel ve yapısal özelikleri ile orijinal taşa benzemelidir. Török ve Přikryl (2010), yaptıkları çalışmada taşların hasar görme mekanizmalarını incelemişler ve taş değişiminde yerel taş kaynaklarının kullanılmasının çok önemli olduğunu ortaya koymuşlardır. Grazzini vd (2020), Ghiffa'daki (Piedmont-İtalya) Sacro Monte anıtsal kompleksinin taş sütunlarının özelliklerini araştırmışlar tarihi taşlarda meydana gelen bozulma olaylarını tahribatsız teknikler kullanmışlardır. Kayseri Sümerbank Bez Fabrikas1, cumhuriyet döneminin gelişmişliğini yansıtan, devlet tarafından kurulan ilk endüstri yapısıdır. Cumhuriyetin kuruluşunun ilk yıllarına ait sosyal yaşam1, teknolojiyi, üretim biçimini ve mimari özellikleri yansıtmaktadır. 2003 yılı sonunda fabrika, tarihi endüstriyel "anıt" olarak tescillenerek koruma altına alınmıştır (Şekil-1) (Kayseri-Kor. Böl. Müdr. Raporu, 2013). Kayseri Tarihi Sümerbank Bez Fabrikası gibi kültürel endüstriyel miras olan bu yapılardaki doğal taşların restorasyonunda, yapıyla uyumlu alternatif taşın nasıl seçileceği önemli bir problemdir. Literatürde bu problemin önemini anlatan çalışmalar vardır (Oakeshott, 1975; Přikryl, 2007; Sousa, 2014; Çelik vd., 2021; Klimek vd., 2021; Aboubacar vd., 2021). Bu sorunun çözümü için alternatif taşın seçimini etkileyen mekanizmanın iyi analiz edilmesine ve objektif ölçütlere dayanan yeni bir yaklaşıma ihtiyaç vardır.

Türkiye Cumhuriyeti Devleti'nin ilk sanayi yatırımı olan Kayseri Tarihi Sümerbank Bez Fabrikası'nın 1934 yılında temeli atılmış, 1935 yılında da fabrika üretime başlamıştır (Şekil 1.).

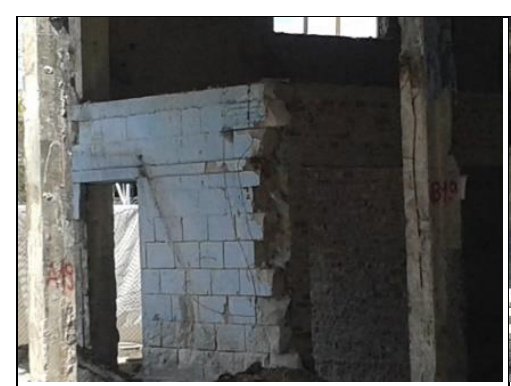

a) Restorasyon Öncesi Duvar (Before Restoration Wall View)

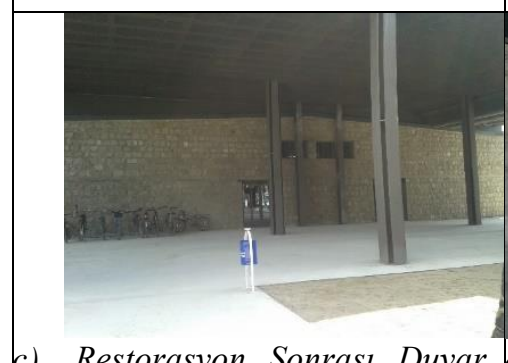

c) Restorasyon Sonrasl Duvar Görüntüsü (After Restoration Wall View)

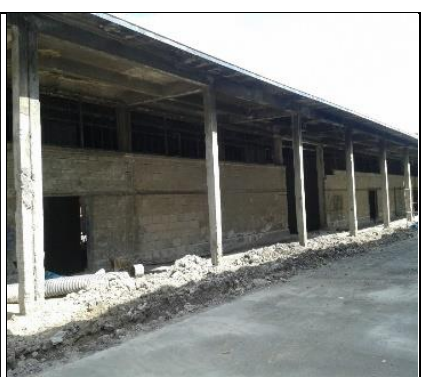

b) Restorasyon Önesi Duvar (Before Restoration Wall View
Şekil 1. Tarihi endüstri yapısı Kayseri Sümerbank Bez Fabrikasının restorasyon öncesi ve sonrası bazı görüntüler (Some images of the historical industrial structure Kayseri Sümerbank Cloth Factory before and after restoration)

Türkiye'nin ekonomik kalkınmasını ve sanayileşme hamlesini temsil eden bu fabrika aynı zamanda kuruluşundan 1994 y1lına kadar, 60 yıl boyunca, kentin sosyal, kültürel, ekonomik oluşumuna etki etmiştir. Rus-Türk ortak yapımı olan fabrika binaları, şehirde yaşanan ortak kent kültürünün önemli bir simgesidir. Bu sebeple fabrikaya ait yapılar korunmalı, varlığ sürdürülmelidir (Kevseroglu, 2011; Özcan ve Güngör, 2019; Onur, 2021; Tanrıverdi ve Çelik, 2021). 
Bu çalışmada, Kayseri Tarihi Sümerbank Bez Fabrikası’nın Abdullah Gül Üniversitesi Sümer Kampüsü'ne dönüştürülmesi için hazırlanmış restorasyon projesi kapsamında, fabrika binalarının duvarlarındaki tahrip olmuş taşların belirlenen deneysel yöntemlerle incelenmesi ve yerine kullanılabilecek taş için uyumluluk değerlendirme ölçütü geliştirilmesi amaçlanmıştır. $\mathrm{Bu}$ ölçüt ile oluşturulan model, yerine kullanılabilecek taşı, çok daha doğru tahmin ederek farklı nitelikteki uyumsuz taşların kullanılma riskini azaltacaktır. Kayseri Tarihi Sümerbank Bez Fabrikası'nda örnek bir uygulaması yapılan bu model, dünyanın diğer bölgelerindeki tarihi yapılar için de uygulanabileceği planlanmaktadır. Ayrıca TÜBITAK, UNESCO, Avrupa Konseyi, ICOMOS ve ICCROM ile iş birliği yapılarak, tarihi endüstri yapıların dışında diğer eski eserler için de araştırma desteği sağlanarak yeni çalışmalar yapılabilir.

Kayseri Tarihi Sümerbank Bez Fabrikası'nın Abdullah Gül Üniversitesi Sümer Kampüsü'ne dönüştürülmesi için bir restorasyon projesi mimar Emre AROLAT tarafindan hazırlanmıştır. MEFA şirketler grubu bu onarım ve yenileme projesinin yapımı için Abdullah Gül Üniversitesi ile sözleşme imzalamıştır. $\mathrm{Bu}$ restorasyon çalışmalarının başarısı, mevcut taşların özelliklerine en uygun taşın belirlenmesine bağlıdır. $\mathrm{Bu}$ sebeple Kayseri Tarihi Sümerbank Bez Fabrikası'nın Abdullah Gül Üniversitesi Sümer Kampüsü'ne dönüştürülmesi için hazırlanmış restorasyon projesi kapsamında, fabrika binalarının duvarlarındaki parçalanmış, kırılmış ve zarar görmüş taşların, fiziksel, mekanik ve kimyasal özelliklerinin, çeşitli tahribatlı ve tahribatsız deney yöntemleriyle incelenmiştir. Orijinal taşı tanımlamaya yarayan tüm deneylere yüzde puanlar verilerek yerine kullanılabilecek uyumlu taşın seçiminde bir ölçüt geliştirmiştir. Böylece, yerine kullanılabilecek taşı, çok daha doğru tahmin edilmesini sağlayan bir model oluşturulmuştur.

\section{Jeolojik Ortam ve Kayserideki Tarihi Eserlerde Kullanılan Taşlar (Geological Environment and Stones Used in Historical Artifacts in Kayseri)}

Roma, Bizans, Anadolu Selçuklu, Osmanlı Devri ve erken Cumhuriyet dönemi mimarisinde doğal taşlar, yaygın biçimde yapılarda kullanılmıştır. Anıtsal taş yapılar şehri olan Kayseri'de de erken cumhuriyet dönemlerine kadar eserler hep taş malzemeyle oluşturulmuştur. Betonarme taşıyıcı sitemler 1930'lardan sonra Kayseri'de yapılmaya başlamıştır. Kayseri Sümer Bez Fabrikası Yerleşkesi'ndeki tüm binalar, taşıyıcı sistemi betonarme, cephe duvarları doğal taş (yonu taşı veya tüf taşı) olarak yapmış olan Kayseri'deki ilk betonarme yapılardır. Yerleşke, çok fonksiyonlu olarak çalışanlarının sosyal, kültürel, eğitimsel ve ikamete yönelik gereksinimlerini karşılayan yönetim binası, üretim binası, sosyal binaları, spor sahası, demir dökümhanesi, elektrik santrali ve hastaneden oluşan mikro ölçekli bir kent modelidir (Kevseroğlu, 2011). Bulunduğu yer aynı isimle adlandırılan Sümer mahallesinde $345.920 \mathrm{~m}^{2}$ alan üzerine inşa edilmiştir. Yıkılan, yağmalanan ve uzun süre hava koşullarına maruz kalarak bozulan duvarlar, mimari elemanların özgünlüğüne zarar vermeden onarılması önemli bir konudur. Kayseri'de erken cumhuriyet dönemine kadar tarihi eserlerde tüf taşı (ignimbirit) ve bazalt taşları kullanılmış ancak bu taşların tam olarak hangi bölgedeki ocaktan geldiği belli değildir. Kayseri ilinin jeolojik yapısı, Erciyes Dağı çevresinde, farklı tüflü kaya birimlerini içermektedir (Şen vd., 2003) (Şekil 2).

e-ISSN: 2148-2683
Kayseri'de çok sayıda tüf taşı çıkaran taş ocakları vardır. Bu taş ocakları Erciyes dağının etrafında geniş sahalara yayılmıştır. Kayseri'de genelde tüf taşı (ignimbirit) yöresel olarak yonutaşı veya Kayseri taşı veya kesme taş olarak da isimlendirilen yapı taşı çıkarılmaktadır (Şekil 2). Kayseri havzasında bulunan bu formasyona mutlak tüf denilemez, ancak tüfe benzediği için tortul tüflü volkanik kaya olarak adlandırılmıştır. "Tüf" ve "tüflü" terimleri şu şekilde tanımlanır: "tüf", volkanik kül ve tozun sıkıştırılmış piroklastik birikintisiyle oluşmuş gözenekli kayaçlardır ve tüflü kaya ise, $\% 50$ 'den fazla tüf içeren kumlu veya killi kayalardır (Acar ve Kaya, 2020).

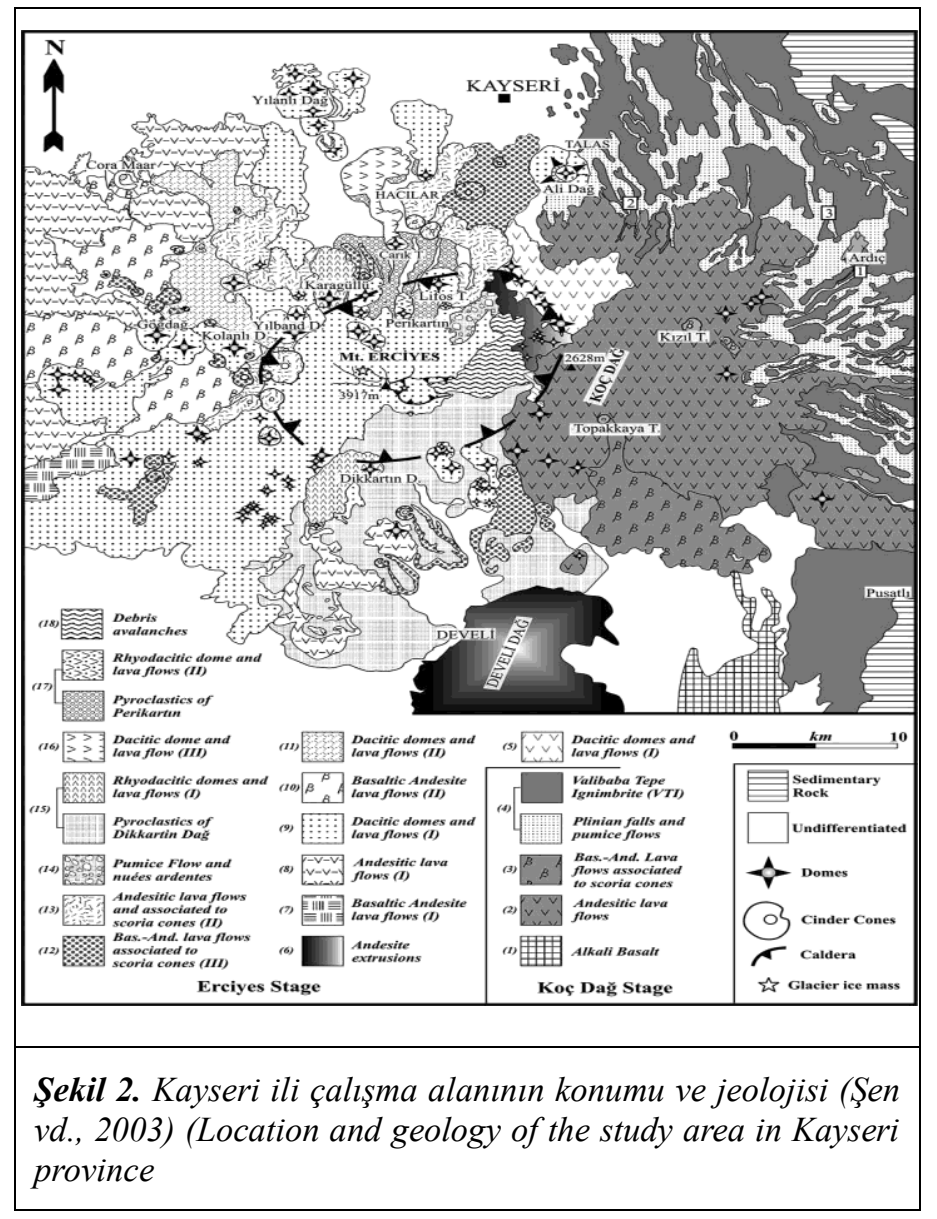

Bu tüflü kayaçlar genel olarak nispeten zayıf dayanıma sahip olmakla birlikte, kaynaklanma derecesine bağlı olarak çok farklı dayanım özellikleri gösterirler (3-50 MPa). Kayseri'deki tarihi yapılarda genellikle, temel seviyesinde işlenmesi oldukça güç ve basınç dayanımı 300-500 MPa arasında (Mohs sertlik derecesi 79) olan bazalt taşı (kara taş) gibi doğal taşlar kullanılmıştır. $\mathrm{Bu}$ tarihi yapıların üst kısımları ise işlenmesi kolay ve düzgün yüzeyli kesilebilen basınç dayanımı 3-50 MPa arasında olan (Mohs sertlik derecesi 1-2) yöresel tüf taşı (yonu taşı/Kayseri taşı) gibi doğal taşlarla tamamlanmıştır. Kayseri ili renkli tabakalı tüfler, lapilli tüfler ve katmanlı kaynaklı, orta kaynaklı ve kaynaksız ignimbiritler içeren ince ve orta taneli tortul kayaçlar yer almaktadır. Bu kayaçlar bazen yumuşak ve zemin benzeri sünek mekanik davranış sergilerken, bazı bölgelerde özellikle İncesu ilçesinde pembe renkli olan tüfler gibi nispeten sert, camsı ve kırılgan kaya davranışı gösterebilirler. Bu kayaçlar büyük litofizal boşluk, mikro boşluklar ve gözenekler gibi süreksizlikler nedeniyle anizotropik elastik deformasyon özellikleri sergilerler. Litofizler, tüflü birimleri oluşturan katmanlı volkanik kül içinde hapsolmuş gaz ceplerinin patlamasıyla oluşur. Kayseri'deki ocaklardan alınan tüflü taşların kimyasal analizleri yapılmış, 
çeşitli oksitlerin \% oranları şeklinde ifade edilmiștir. Bunlar $\mathrm{SiO}_{2}$, $\mathrm{Al}_{2} \mathrm{O}_{3}, \mathrm{Fe}_{2} \mathrm{O}_{3}, \mathrm{FeO}, \mathrm{Na}_{2} \mathrm{O}, \mathrm{K}_{2} \mathrm{O}, \mathrm{CaO}, \mathrm{MnO}, \mathrm{MgO}, \mathrm{TiO}_{2}, \mathrm{P}_{2} \mathrm{O}_{5}$, $\mathrm{H}_{2} \mathrm{O}$ ve $\mathrm{CO}_{2}$ olarak adlandırılan tüflü kayacın ana elementleridir. Taş ocaklarından alınan numuneler için kimyasal analiz sonucunda bu ana elementlerden (derinlik yaklaşık 1 ila $5 \mathrm{~m}$ ) $\mathrm{SiO}_{2}$ oran $1 \% 60-77, \mathrm{Al}_{2} \mathrm{O}_{3}$ oran $1 \% 14,88$ ila $\% 15,87, \mathrm{MgO}$ oran $1 \% 0,38$ 0,89 aralığındadır. $\mathrm{Fe}_{2} \mathrm{O}_{3}$ aralığ $\% 3,63-4,16, \mathrm{TiO}_{2}$ aralığ $0,65-$ $0,73, \mathrm{CaO}$ aralığ $\% 1,65-3,57, \mathrm{Na}_{2} \mathrm{O}$ aralığ $4,77-5,88, \mathrm{~K}_{2} \mathrm{O}$ $\% 2,47-3,07, \quad \mathrm{P}_{2} \mathrm{O}_{5}$ aralığ $0,15-0,26, \quad \mathrm{MnO} \quad 0,07-0,11 \%$ dir. Ortalama kimyasal bileşim $\mathrm{SiO}_{2}(\% 67,73), \mathrm{TiO}_{2}(\% 0,5), \mathrm{Al}_{2} \mathrm{O}_{3}$ $(\% 15,44), \mathrm{Fe}_{2} \mathrm{O}_{3}(\% 0,69), \mathrm{FeO}(\% 2,4), \mathrm{MnO}(\% 0,09), \mathrm{MgO}$ $(\% 0,63), \mathrm{CaO}(\% 2,35), \mathrm{Na}_{2} \mathrm{O}(\% 4,85), \mathrm{K}_{2} \mathrm{O}(\% 2,85), \mathrm{P}_{2} \mathrm{O}_{5}$ $(\% 0,18)$, diğer $(\% 1,15)$ olarak elde edilmiştir. Bu piroklastik tüflü kayaçların kimyasal içerikleri birbirine yakın olmakla birlikte, kaynaklanma dereceleri farklı olduğundan birim ağırlıkları, mukavemetleri ve renkleri (kahverengi, gri, gri pembe vb.) farklıdır (Acar ve Kaya, 2020).

\section{Materyal ve Yöntem (Material and Method)}

Geçmişten günümüze kadar pek çok araştırmacı yerine kullanılacak taşın orijinal taşa uygunluğunu araştırmak amacıyla çözüm yolları üzerinde çalışmaktadır. Bu çalışmalarda, yeni taşın fiziksel ve estetik açıdan uygun olması ve ideal olarak mevcut yapı taşı ile aynı tipte veya mümkün olan en yakın muadili olması gerektiğini belirtmişlerdir (Oakeshott, 1975; Přrikryl, 2007; Török ve Přikryl, 2010; Grazzini vd.,2020; Del vd., 2020; Salvatici vd., 2020; Çelik vd., 2021; Klimek vd., 2021). Kayseri Tarihi Sümerbank Bez Fabrikası'nda yerine taşların belirlenmesi için bir örnek uygulama çalışması yapılmıştır. Yapıda kullanılan mevcut taşlar ve yerine kullanılabilecek taşları tanımlamaya yarayan, tahribatsız ve tahribatlı tüm deneyler türüne göre gruplara ayrılmıştır. Elde edilen deney sonuçlarına göre, yerine kullanılacak taşların, mevcut taşa benzerliği için bir ölçüt geliştirilmiştir. Böylece yerine kullanılacak taşı, objektif kriterlere göre çok daha doğru tahmin etmemize olanak veren ve farklı nitelikteki uyumsuz taşların kullanılma riskini azaltan bir model oluşturulmuştur. Mevcut taşın yerine kullanılacak uyumlu veya daha iyi özelliklere sahip yeni taşı tespit etmede pratik ve ekonomik yönleri olan bu model, bilim ve teknolojiye katkısı yönünden önemlidir. Kayseri Sümerbank Bez Fabrikası'nın duvarlarında zarar görmüş taşların yerine kullanılabilecek alternatif taşların seçilmesi için geliştirilen bu yöntem, diğer benzer tarihi eserler için bir model olacak ve örnek teşkil edecektir.

$\mathrm{Bu}$ araştırmada beş ana iş aşaması ve her aşamanın da alt aşamaları olacak şekilde planlanmıştır. Yapılan modelin aşamaları Tablo 1'de şematik olarak gösterilmiştir. Tarihi duvarların restorasyonunda, yerine kullanılan taşların uyumluluk değerlendirirken ilk aşama ön araştırma ve saha gözlemidir. $\mathrm{Bu}$ aşamada, sahada inceleme yapılır ve olası problemler yerinde incelenir. Arazide, öncelikle parçalanmış duvar taşlarının olup olmadığı araştırılır varsa bunlar üzerinde laboratuvar deneyleri yapmak için taş örnekler alınır. Arazide tahribatsız veya zorunlu olması durumunda tahribatlı deneysel çalışma yapılacak yerler belirlenir. Bunların arasında duvar çatlakları, hasar görmüş duvar taşlarının konumları ve hasar miktarları, yapı temelinde oturma olup olmadığı, taşlarda fiziksel ve kimyasal aşınma durumları, yapıda daha önce restorasyon yapılıp yapılmadığı ve kullanılmış taşların türleri belirlenir. Üçüncü aşama yeni taşın mevcut taşlara göre renk açısından öncelik belirleme aşamasıdır Taş seçiminde öncelik, jeolojik kökeni, renk, doku ve desen olarak mevcut yapıya uyumlu olan alternatif taş/taşların tespit edilmesidir. $\mathrm{Bu}$ amaçla, kimyasal analiz yapılarak jeolojik kökeni ve renk ölçümü yapılarak mevcut ve yeni taşın renk uyumu görsel ve sayısal (dijital kamera) ölçüm yapılarak araştırılır (Schalkoff, 1989; Winkler 1997).

Tablo 1 Tarihi duvarda mevcut taşın yerine yeni taşın kullanımı için önerilen modelin aşamaları

(Suggested modeling steps for the use of new stone instead of existing stone on the historic wall)

\begin{tabular}{|c|c|c|c|c|}
\hline $\begin{array}{l}\text { 1.Aşama: } \\
\text { Ön araştır ma, } \\
\text { Saha gözlemi }\end{array}$ & $\begin{array}{l}\text { 2.Assama } \\
\text { Tarihi Yapı ile ilgili } \\
\text { Bilgi Toplama }\end{array}$ & $\begin{array}{l}\text { 3.Așama } \\
\text { Taş seçiminde } \\
\text { Öncelik } \\
\text { Belirleme }\end{array}$ & $\frac{\text { 4.Așama }}{\text { Deneysel Analiz ve Model }}$ & $\begin{array}{l}\text { 5.Aşama } \\
\text { Mevcut ve yeni } \\
\text { taşların seçimi }\end{array}$ \\
\hline $\begin{array}{l}\text { Mevcut taşların ve } \\
\text { sahada deneysel } \\
\text { çalışma alanının ön } \\
\text { araştırılması, Yerel } \\
\text { taş kaynaklarının } \\
\text { yerinde araştırılması }\end{array}$ & $\begin{array}{l}\text {-Duvar çatlakları } \\
\text {-Daha önce } \\
\text { restorasyon olup } \\
\text { olmadığı } \\
\text {-Hasarın konum ve } \\
\text { miktarı } \\
\text {-Temelde oturma v.s } \\
\text { bilgilerin toplanması }\end{array}$ & $\begin{array}{l}\text { Taşların jeolojik } \\
\text { köken, renk, } \\
\text { doku ve desen } \\
\text { olarak uyumu } \\
\text { için kimyasal } \\
\text { analiz ve renk } \\
\text { ölçümü } \\
\text { yapılması. }\end{array}$ & $\begin{array}{l}\text { Taşların, fiziksel ve mekanik } \\
\text { özelliklerini gösteren } \\
\text { parametrelerin ve bunlar } \\
\text { arasındaki doğrusal ilişkilerin } \\
\text { bulunması, Mevcut taşın yerine } \\
\text { yeni taşın seçimini etkileyen } \\
\text { kriterlerin belirlenmesi ve bir } \\
\text { yüzde puanlama modeli } \\
\text { oluşturulması }\end{array}$ & $\begin{array}{l}\text { Oluşan model ile } \\
\text { mevcut ve yeni } \\
\text { taşların puanlanması } \\
\text { ve karşılaştırılması, } \\
\text { yeni taşın, hangi } \\
\text { mevcut taşların yerine } \\
\text { kullanılacağının } \\
\text { bulunması. }\end{array}$ \\
\hline
\end{tabular}

Tarihi eserde var olan mevcut taşların, yapıda kullanılacak yeni taşla renk, doku ve desen olarak uyumlu olabilenler belirlenir. Dördüncü aşama modelleme ve analiz aşamasıdır. Taşların, Avrupa standartlarına uygun muayene ve deneyler ile analizleri yapılır, fiziksel ve mukavemet özellikleri belirlenir. Dördüncü aşama, deneylerden elde edilen aşınma kaybı (mm), Birim Hacim Ağırlık (kuru) BHA (kN/m³), SH (Schmidt Sertliği), Özgül Ağırlık G s $_{\mathrm{s}}$ Birimsiz), Su emme (\%), Porozite n (\%), Ultra ses hızı $\mathrm{V}_{\mathrm{p}}(\mathrm{km} / \mathrm{s})$, Nokta yükleme dayanım endeksi $\mathrm{I}_{\mathrm{s}}(\mathrm{MPa})$,
Brazilian dolaylı çekme dayanımı, BRT (MPa) parametrelerin bulunmasıdır. Daha sonra, alternatif taş seçme kriteri belirlenerek bir model oluşturulur. Beşinci ve son aşama ise seçim yapma aşamasıdır. Yeni taşın orijinal taşlara göre ne kadar daha iyi özelliklere sahip olduğu (benzerlik fazlası) veya daha kötü özelliklere sahip olduğu (benzerlik eksiği), önem derecesine göre puanlanır. Tarihi duvarın bazı mevcut taşlarının değişimi için, yeni taşın uygun olup olmadığı toplamdaki puan ile belirlenir. 


\subsection{Modeldeki Kullanılan Parametreler ve Toplam \\ Puanin Hesabi (Parameters Used in the Model and Calculation of the Total Score)}

Toplam puan, tarihi yapıdaki taşların kullanılacak yeni taşa göre uyumluluğunu gösteren yüzde benzerlik fazlası veya eksiğ $i$ (mevcut taşın parametrelerinin yeni taşa göre yüzde bağıl hatası gibi düşünülebilir) hesaplanır (Tablo 2). Burada yeni taş referans noktası olarak alınır. Tablo 2'de tanımlanan formüle göre, yeni taşın, kendisine karşı bir benzerlik fazlası veya eksiği olmadığı için puanı (bağıl hata) sıfırdır ancak yeni taş referans alınarak diğer mevcut taşların bu yeni taşa göre benzerlik fazlası veya eksiği olmaktadır. Sonuç olarak, yeni taşın toplam puanı sıfır olduğu için, negatif toplam puana sahip tüm mevcut taşların yerine yeni taş kullanılabilir ancak sıfırdan büyük toplam puana sahip mevcut taşlarda ise yeni taş kullanılamaz (Tablo 2) Taşların değerlendirme kriterleri için ana fiziksel özelliklerin, Su emme (\%), Özgül ağırlık Gs, Birim hacim ağırlık (kuru) BHA $\left(\mathrm{kN} / \mathrm{m}^{3}\right)$, Porozite n (\%), Ultrases boyuna dalga hızı Vp (km/s) ve mekanik dayanımı için Schmidt sertliği SH, Aşınma kaybı (mm), Nokta yükleme Is (MPa), Brazilian dolaylı çekme BRT (MPa), Tek eksenli basınç UCS (MPa) dayanım deneyleridir.

TOPLAM PUAN (TOTAL SCORE)

$$
\begin{gathered}
=\overbrace{\% 7 . X_{1}+\% 7 . X_{2}+\% 7 . X_{3}+\% 7 . X_{4}+\% 7 . X_{5}}^{\text {Fiziksel Özellikleri } \% 35}+\overbrace{\% 15 . X_{6}+\% 15 . X_{7}+\% 15 . X_{8}}^{\text {BasınçDayanımları } \% 45} \overbrace{\% 10 . X_{9}}^{\text {Çekme Dayanımı \%10 }} \\
+\overbrace{\% 10 . X_{10}}^{\text {Aşınma Kaybı \%10 }}
\end{gathered}
$$

Modeldeki Değişkenler (Variables in the model): $\mathrm{X}_{1}, \mathrm{X}_{2}, \mathrm{X}_{3}, \mathrm{X}_{4}, \mathrm{X}_{5}, \mathrm{X}_{6}, \mathrm{X}_{7}, \mathrm{X}_{8}, \mathrm{X}_{9}, \mathrm{X}_{10}$ aşağıda açıklanmıştır

\section{Fiziksel Özellikleri (Physical Characteristics)}

$\mathrm{X}_{1}=$ Taşların Birim Hacim A ğırlık (BHA) uyumluluk yüzdesi (\%7),

$\left(\mathrm{X}_{1}=\right.$ [Mevcut taşın BHA değeri- Yeni taşın BHA değeri / Yeni taşın BHA değeri $]$ *100.)

$\mathrm{X}_{2}=$ Taşların Özgül Ağırlık $\left(\mathrm{G}_{\mathrm{s}}\right)$ uyumluluk yüzdesi (\%7),

$\left(\mathrm{X}_{2}=\left[\left(\right.\right.\right.$ Mevcut taşın $\mathrm{G}_{\mathrm{s}}$ değeri- Yeni taşın $\mathrm{G}_{\mathrm{s}}$ değeri $) /$ Yeni taşın $\mathrm{G}_{\mathrm{s}}$ değeri] *100.).....

$\mathrm{X}_{3}=$ Taşların Porozite (Gözeneklilik) uyumluluk yüzdesi (\%7),

$\left(\mathrm{X}_{3}=-[(\right.$ Mevcut taşın Porozite değeri- Yeni taşın Porozite değeri)/ Yeni taşın Porozite değeri $] * 100)$

$\mathrm{X}_{4}=$ Taşların Su emme uyumluluk yüzdesi (\%7),

$\left.\left(\mathrm{X}_{4}=\text { - [(Mevcut taşın su emme değeri- Yeni taşın su emme değeri) / Yeni taşın su emme değeri }\right]^{*} 100\right)$

$\mathrm{X}_{5}=$ Taşların Ultrases geçiş hızı $\left(\mathrm{V}_{\mathrm{p}}\right)$ 'nin uyumluluk yüzdesi (\%7),

$\left(\mathrm{X}_{5}=\left[\left(\right.\right.\right.$ Mevcut taşın $\mathrm{V}_{\mathrm{p}}$ değeri - Yeni taşın $\mathrm{V}_{\mathrm{p}}$ değeri $) /$ Yeni taşın $\mathrm{V}_{\mathrm{p}}$ değeri $]$ *100.)

\section{Basınç Dayanımları (Compressive Strengths)}

$\mathrm{X}_{6}=$ Taşların Schmidt Çekici yöntemi ile yüzey sertliğinin $(\mathrm{SH})$ uyumluluk yüzdesi (\%15),

$\left(\mathrm{X}_{6}=[(\right.$ Mevcut taşın SH değeri- Yeni taşın SH değeri) / Yeni taşın SH değeri $]$ *100.)

$\mathrm{X}_{7}=$ Taşların Nokta Yükleme Dayanım $\left(\mathrm{I}_{\mathrm{s}}\right)$ uyumluluk yüzdesi (\%15),

$\left(X_{7}=\left[\left(\right.\right.\right.$ Mevcut taşın $I_{s}$ değeri - Yeni taşın $I_{s}$ değeri $) /$ Yeni taşın $I_{s}$ değeri $]$ *100. $)$

$\mathrm{X}_{8}=$ Taşların Tek Eksenli Basınç Dayanımı (UCS) uyumluluk yüzdesi (\%15),

$\left(\mathrm{X}_{8}=[(\right.$ Mevcut taşın UCS değeri- Yeni taşın UCS değeri) / Yeni taşın UCS değeri $]$ *100.)

\section{Çekme Dayanımı (Tensile Strength)}

$\mathrm{X}_{9}=$ Taşların Brazilian Dolaylı Çekme Dayanımı (BRT) uyumluluk yüzdesi (\%10),

$\left(\mathrm{X}_{9}=[(\right.$ Mevcut taşın BRT değeri-Yeni taşın BRT değeri $) /$ Yeni taşın BRT değeri $]$ *100.)

\section{Aşınma Kaybı (Abrasion Loss)}

$\mathrm{X}_{10}=$ Taşların Aşınma Dayanımı uyumluluk yüzdesi (\%10),

$\left(\mathrm{X}_{10}=-[(\right.$ Mevcut taşın aşınma kaybı-Yeni taşın aşınma kaybı)/ Yeni taşın aşınma kaybı $]$ *100. $)$

$\mathrm{Bu}$ deney sonuçlarını en çok etkileleyen taş özelliğinin kayanın gözenekli sistemine bağlı olduğu pek çok araştırmacı tarafından gösterilmiştir (Adriani ve Walsh, 2003; Sousa, 2014;
Martínez-Martíne ve Waz vd., 2018; Gibeaux vd., 2018; Del vd., 2020; Çelik vd., 2021; Klimek vd., 2021). Taşların basınç dayanımı ise, restorasyon çalışmalarında olduğu kadar yeni 
inşaatlarda da yapı malzemelerinin kalitesini belirleyen en önemli unsurlardan bir diğeridir. Dayanıklılık testleri zaman alıcı, yıkıcı ve maliyetli olduğundan, tüf gibi gözenekli taşların dayanıklılığını Nokta yükleme, Brazilian dolaylı çekme gibi taşların küçük parçaları ile test edilebilen çok az tahribatlı veya Schmidt çekici, Ultra ses hızı gibi tahribatsız yöntemler tercih edilmiştir (Sousa, 2014; Salvatici vd., 2020; Aboubacar vd., 2021). Bu çalışmalarda, taşların, Su emme, Porozite, Özgül ağırlık, Birim hacim ağırlık parametreleri araştırılmış ve taş basınç dayanımına olan etkisini değerlendirmiştir. Bunun yanında, aşınma deneyi aşınmaya karşı taşın duyarlılığını kontrol ettiği için taş seçiminde negatif puan göstergesi olarak kullanılmıştır (Aboubacar vd., 2021). Bunların taşlara negatif etki eden en agresif mekanizmalar olduğu pek çok araştırmacı tarafindan da kabul edilmektedir (Sousa, 2014; Aboubacar vd. 2021). Bu araştırmada, taşların aşınma durumların basınç dayanımı ile ilişkisi de incelenmiştir. Yapıdaki taşların ve yerine kullanılacak yeni tüf taşının aşınmaya bağlı davranışlarının yanı sıra, fiziksel ve mukavemet özellikleri bulunarak, yeni taşın mevcut taşlardan hangilerine uygun olacağını tahmin eden bir model geliştirilmiştir. Ekonomik ve pratik uygulanabilirliği olan bu araştırma, restore edilecek yapının tahribatına neden olmadan da bir çözüm önerisi sunmaktadır. Ayrıca, daha az bilinen Geniş disk aşınma, Nokta yükleme ve Brazilian dolaylı çekme gibi dünyaca kabul edilmiş test yöntemleri önerilmektedir. Buradaki amacımız, alternatif taşın seçiminde yapıya zarar vermeyecek veya en az zararla pratik ve ekonomik bir ölçüt geliştirmektir. Böylece, bu çalışmada kullanılan çözüm yöntemleri, restorasyon teknolojisinin gelişmesine katkı sağlayacaktır.

\subsection{Yerinde ve Laboratuvarda Taşların Test \\ Edilmesi (Testing of Stones with In-situ and Laboratory Studies)}

$\mathrm{Bu}$ çalışmada, özgün malzeme yerine kullanılacak taşın doğru olarak tahmin etmemize yarayacak pratik ve ekonomik bir model önerilmiştir. Bu model, taş kaynaklarındaki değişkenlik, pahalı ve karmaşık yöntemlerin uygulanması ve ülkeden ülkeye değişen laboratuvar deney standartlarının seçimindeki belirsizliklerin önlenmesine katkıda bulunacaktır. Karmaşık test yöntemleri kullanılmadan önce, daha basit olan görsel muayene, tahribatsız deneyler ile taş hakkında oldukça önemli bilgiler elde edilir. Tahribatsız yöntemler termografi, flatjack, Schmidt sertliği, radar araştırmaları, ultra ses gibi deney yöntemleri olarak sıralanabilir. Kullanım kolaylığı ve ekonomik açıdan, en sık kullanılan deneyler ise taşınabilir ultrasonik ses hızı testi ve mekanik özelliklerin yerinde tespiti için Schmidt çekici testidir. Bu çalışmada, tahribatsız deneylerden yaygın olarak kullanılan Schmidt sertliği $(\mathrm{SH})$ ve ultra ses $\left(\mathrm{V}_{\mathrm{p}}\right)$ test yöntemleri tercih edilmiştir. Bunun yanında taşların iç ve dış faktörlerinin etkilerinin değerlendirilmesi için bazı standart olmayan deneyler de kullanılmaktadır (Aboubacar vd., 2021). Bu çalışmada, tahribatlı taş muayenesi için uygulaması basit, zaman almayan, ekonomik, en düşük tahribatı veren ve çağdaş mekanik deney yöntemleri olan Nokta yükleme $\left(\mathrm{I}_{\mathrm{S}}\right)$, Brazilian dolaylı çekme (BRT), Tek eksenli basınç (UCS), Geniş Disk Aşınma (GD) deneyleri tercih edilmiş ve (ISRM,1981) ve (TS699,2009) standartlarına uygun olarak deneyler yapılmıştır.

Günümüzde bilim insanları, tarihi yapılardaki taşların jeolojik kökenini, kimyasal bileşimini belirlemek, uzun vadeli davranışı hakkında bilgi sahibi olmak ve yerine kullanılacak taşın kökeninin mevcut taşa uygunluğunu araştırmak amacıyla çeşitli standartlara uygun mineralojik ve kimyasal deneyler yapmaktadır. Bunlar genellikle Avrupa Standartları, Uluslararası Kaya Mekaniğgi Birliği (ISRM, 1981) tarafından önerilen yöntemlerdir. Bu çalışmada, Kayseri'deki tüflü taşların kimyasal analizleri yapılmış, ana elementler olarak $\mathrm{SiO} 2, \mathrm{Al} 2 \mathrm{O} 3, \mathrm{Fe}_{2} \mathrm{O}_{3}$, $\mathrm{FeO}, \mathrm{Na}_{2} \mathrm{O}, \mathrm{K}_{2} \mathrm{O}, \mathrm{CaO}, \mathrm{MnO}, \mathrm{MgO}, \mathrm{TiO}_{2}, \mathrm{P}_{2} \mathrm{O}_{5}, \mathrm{H}_{2} \mathrm{O}$ ve $\mathrm{CO}_{2}$ oksitlerin \% oranları şeklinde ifade edilmiştir. Laboratuvar ortamında ise araziden alınan yeterli sayıda numune üzerinde birim hacim ağırlık, porozite, su emme ve özgül ağırlık deneyleri yapılmıştır (Şekil 3).

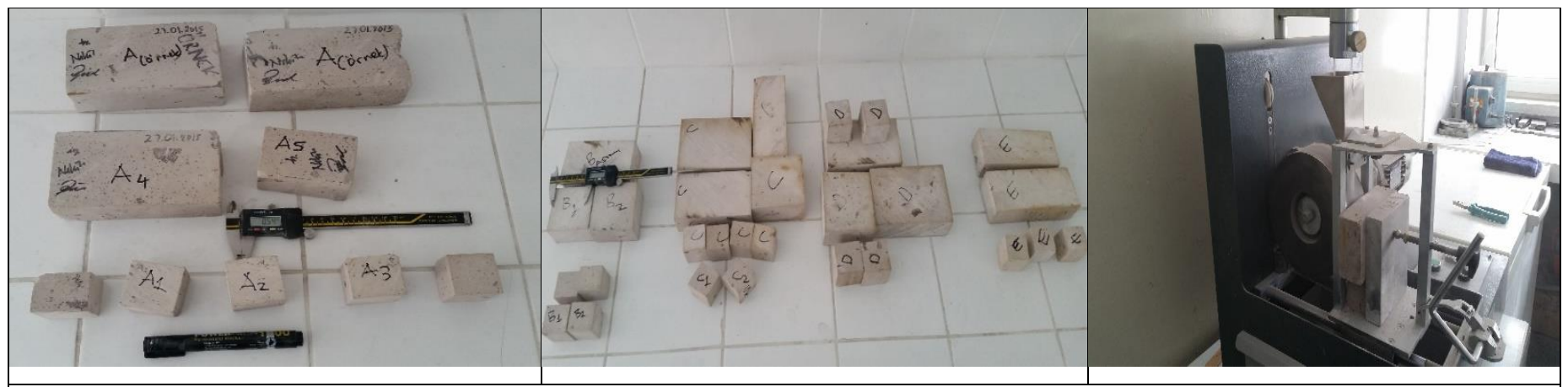

Sekil 3. Test edilen tüf taşlarının deney öncesi ve deney sırasında bazı numune görüntüleri (Some images of tuff stone samples used in the experiment before and during the experiment)

Taşlarının renginin belirlenmesinde görsel ölçüm ve sayısal olarak standart bilgisayarlarla çalışan dijital kameralar kullanılarak iki yöntemle yapılmıştır. Görsel ölçüm için taş renginin, bilinen sabit renk skalaları ile karşılaştırılması ile renk tespit süresi oldukça kısa ve maliyeti düşüktür. Bu yöntemde taş ve skala aynı ışı kaynağı altında, özellikle en ideali gün ışığında öğlen saatlerinde (gün 1şığının beyaz renk yaklaşık 6000 Kelvin olunca) karşılaştırılmıştır. Gözlemci, taşın rengini seçerken 1 şık kaynağı önemlidir. Bir taşın algılanan rengi, maruz kaldı $\breve{g}_{1}$ 1şığın türü, diğer renkli objelerle olan ilişkisi ve gözlemcinin değerlendirme yeteneğinden etkilenir. Dolayısıyla taşlar farklı ortamlarda farklı renklerde görünebileceği için renk belirlemede tutarsızlıklar olmakta, standardizasyon sağlanamamaktadır. Bilgisayar uygulamalarıyla çalışan dijital renk ölçüm cihazlarının kullanımı ile daha objektif, tekrarlanabilir ve hılı ölçümler yapılabilmektedir. Bilgisayar görüntü analizlerinde bilgisayar monitörlerinde görüntülenen görüntüler RGB renk kodlarını içeren üç boyutlu renk matrisi ile tanımlanır. Bilgisayar ekranında görüntülenen herhangi bir görüntünün renkleri, her monitör pikseli için RGB renklerinin birleştirilmesiyle üretilir. 
Bilgisayarların grafik kartı teknolojisi, her ana renk (RGB) bandını 256 eşit bölümlere böler (Schalkoff, 1989; Winkler 1997). Tablo 4'te, taşlarda gözlemlenen bazı ana renkler ve bunların RGB renk kodları göstermektedir. Sayısallaştırılmış renk değerleri, dijital RGB kodlarıyla belirtilmiştir. Schmidt sertlik testi, ISRM'ye (1981) göre 2,207 Nm darbe enerjisine sahip Ntipi çekiç ile gerçekleştirilmiştir. Tüm testler, ISRM (1981) tarafından tanımlanan yaklaşık $23 \mathrm{~kg}$ ağırlığa sahip çelik bir V bloğunda çekiç dikey olarak aşağı ve dik açıyla tutularak normalize edilmiştir. Taş blokları üzerinde geniş bir alanda $(20 \mathrm{~cm} \times 20 \mathrm{~cm})$ bulunan sıva kaldırılmış ve zımpara taşı ile yüzey düzeltilerek temizlenmiştir. Yapılan tekli darbelerden gelen 20 geri tepme değeri kaydedilmiş ve üst on değerin ortalaması, taşın geri tepme sayısı olarak alınmıştır. Çekiç okumaları duvar üzerinde yapılmış ve $5 \mathrm{~cm}$ uzunluğundaki küp numuneler üzerinde tekrarlanmıştır. Ölçüm üzerindeki herhangi bir anizotropik etkiyi ortadan kaldırmak için her numunenin mikroskobik kusurlar açısından incelenmiştir. Yerinde testin, doğal yüzeylerin pürüzlülüğü, yüzeyin altındaki çatlakların varlığı için kontrol edilmiş ve kuru yüzey olmasına da dikkat edilmiştir. Ultrasonik dalga hızı $\left(\mathrm{V}_{\mathrm{p}}\right)$ yönteminde, ultrasonik hız dalgasının yayılma değişimleri analiz edilir. Ultrasonik $\mathrm{P}$ dalga hızı katılarda, sıvılardakinden, sıvilarda da havadakinden daha hızlı bir şekilde yayılmaktadır. Taşlarda ultrasonik hız değerini etkileyen birçok faktör bulunmaktadır. Bunlardan önemli olanları; taşın tipi, dokusu, dane boyutu ve şekli, Porozitesi, yoğunluğu, su içeriği, sıcaklığıdır. Malzeme homojenliğinin incelenmesini mümkün kılan bu yöntem, doğal taş yapıların değerlendirilmesinde önemli yöntem olarak kabul edilebilir. Darbe hızının belirlenmesinde ses dalgasının geçtiği duvar kalınlığı, uzunluk (cm) olarak belirlenir ve geçiş süresi mili saniye $(\mu \mathrm{s})$ bulunur. Uzunluğun zamana oranı ile sismik hız $\left(\mathrm{V}_{\mathrm{p}} \mathrm{km} / \mathrm{s}\right)$ değerleri hesaplanır. Bu çalışmada, kullanılan taşların $V_{p}(\mathrm{~km} / \mathrm{s})$ değerleri Pundit ultrasonik hız ölçüm cihazı ile belirlenmiştir. Pundit cihazında bir alıcı, dönüştürücü ve bir gösterge bulunur. Göstergeden, sadece ultra ses dalgalarının süresi okunur. Nokta yük dayanımı testi, genellikle kayanın basınç dayanımının dolaylı bir ölçüsü olarak bilinmektedir. Bu test, numune hazırlama kolaylığı, küçük şekilsiz taş parçalarına uygulanabilirliği ve saha uygulamaları nedeniyle pratik olarak kullanılmıştır. $\mathrm{Bu}$ çalışmada, ISRM'ye (1981) göre her gruptaki numunelerin düzensiz şekilli parçalarından, laboratuvarda hazırlanan yaklaşık $5 \mathrm{~cm}$ çapında, $2,5 \mathrm{~cm}$ kalınlığında üç silindirik disk haline getirilmiş numuneler üzerinde eksenel nokta yük testleri yapılmıştır. Yapılan testlerin ortalaması alınarak kırılma yükünün eşdeğer çap olan kalınlığının karesine bölünerek her taş grubunun nokta yükü dayanım endeksi $\mathrm{I}_{\mathrm{s}}(\mathrm{MPa})$ bulunmuştur. Tüm testler laboratuvarda hava ile kurutulan numuneler ile yapılmıştır. Brazilian dolaylı çekme deneyi, disk şeklinde hazırlanmış kayaç örneklerinin çapsal yükleme altında çekilme dayanımlarının dolaylı yoldan tayini amacıyla yapılmıştır. Örneklerinin uçlarından sabitlenerek çekilmesi şeklinde uygulanan doğrudan çekme deneyindekine göre genellikle biraz daha yüksek çekme dayanımları elde edilmektedir. Örneklerin deneye hazırlanması ve deneyin yapılışı açısından daha pratik olması nedeniyle Brazilian yöntemi yaygın şekilde kullanılmaktadır. Bu yöntemle, düzensiz şekilli duvar taş parçalarından, laboratuvarda hazırlanan her grup taş için 3 adet yaklaşık $5 \mathrm{~cm}$ çapında, 2,5 cm kalınlığında silindirik disk haline getirilmiş numuneler üzerinde testler yapılmıştır. Kırılma kuvvetinin kesit alanına (çevre uzunluğunun yarısı ile kalınlığının çarpımı) bölünmesiyle elde edilen deneyin ortalaması alınarak her grubun BRT (MPa) değerleri bulunmuştur. Tek eksenli basınç (UCS) deneyi iki adet $5 \times 5 \times 5 \mathrm{~cm}^{3}$ boyutlarında ve her grupta üç adet çap $5 \mathrm{~cm}$ boyu $10 \mathrm{~cm}$ olan silindir numuneler ile tabakaya paralel ve normal kesilmiş yüzeyi pürüzsüz numuneler kullanılarak yapılmıştır. Kırılma kuvvetinin alanına oranı olacak şekilde ve ortalaması alınarak her grubun Tek eksenli basınç (UCS) değeri hesaplanmıştır. Geniş disk aşınma deneyi (GD) kısa deney süresi ve pratik kullanım özellikleri nedeniyle kullanılmıştır. Çalışmada her gruptan iki adet $10 \mathrm{~cm} \times 10 \mathrm{~cm} \times 5 \mathrm{~cm}$ numune kullanılmış ve 2 örneğin toplamda 4 yüzeyinde olmak üzere aşınma deneyi yapılmıştır. GD aşınma deneyinde, aşındırıcı toz kullanılarak $200 \mathrm{~mm}$ çapında ve $70 \mathrm{~mm}$ genişliğinde disk ile numunelerin yüzeyleri aşındırılmıştır. Dönen diskin aşındırdığı mesafenin ölçümü yapılarak dört deneyin ortalaması alınarak her gruptaki taşların aşınma kaybı değerleri bulunmuştur.

\section{Bulgular ve Tartışmalar (Results And Discussions)}

Kayseri Tarihi Sümerbank Bez Fabrikası'nın Abdulah Gül Üniversitesi Sümer Kampüsü'ne dönüştürülme sürecinde, Kayseri Gesi ilçesindeki taş ocağından (A Grup taşlar) ve tarihi yapının Büyük Ambar Binası ile Giriş Kapısı’ndan alınan tüf taşı numuneleri (B,C,D,E Grup taşları) üzerinde Tek Eksenli Basınç Dayanımı (UCS), Birim Hacim Ağırlık (Kuru) (BHA), Porozite (n), Su Emme (Ağırlıkça), Ultrases boyuna dalga hızı (Vp), Schmidt Sertliği (SH), Nokta Yükleme Dayanım Endeksi (Is), Brazilian Dolaylı Çekme Dayanımı (BRT), Geniş Disk Aşınma (GD) ve Özgül Ağırlık (Gs) deneyleri yapılmıştır. Kayseri Üniversitesi Teknik Bilimler Meslek Yüksekokulu İnşaat Bölümü Malzeme Laboratuvarı'nda yapilan bu deneylerde A kodlu numune yeni taş, B-C-D-E kodlu taşlar ise duvarda mevcut taşlardır. Yapılan bu deneylerin sonuçları Tablo 3 'te görülmektedir.

Bağımlı değişken UCS ile diğer bağımsız değişkenler arasındaki ilişkilere bakıldığında, taşların mekanik özelliklerini olumsuz yönde etkilen en önemli unsurların başında Porozite miktarı gelmektedir. İnceleme yapılan taşlarda \%55 ile en yüksek Porozite değerine sahip olan (E) numunesi, ortalama basınç dayanım değeri açısından da en düşük seviyede olmuştur. Tek eksenli basınç dayanımı değerleri (A) grubu tüf taşında 13,51 $\mathrm{MPa}$, (B) grubu tüf taşında 9.19 $\mathrm{MPa}$, (C) grubu tüf taşında 9,73 $\mathrm{MPa}$, (D) grubu tüf taşında $20,74 \mathrm{MPa}$ ve (E) grubu tüf taşında 4,84 $\mathrm{MPa}$ olarak bulunmuştur. Tüm grup numuneler için bu modeli önemli oranda etkileyen basınç dayanımının diğer deneysel parametreler arasındaki doğrusal ilişkiyi göstermek için, eğriye ne kadar iyi uyduğunu gösteren bir ölçüt olarak determinasyon katsayısı $\left(\mathrm{R}^{2}\right)$ değerleri Şekil-4 de verilmiştir. 
Tablo 3. Taşların fiziksel ve mekanik deneylerden elde edilen parametreleri (Parameters of stones obtained from physical and mechanical experiments)

\begin{tabular}{|c|c|c|c|c|c|c|c|c|c|c|}
\hline Deney Numune Grupları & $\begin{array}{c}\text { UCS } \\
(M p a)\end{array}$ & $\begin{array}{c}B H A \\
\left(k N / m^{3}\right)\end{array}$ & $\begin{array}{c}\text { Porozite } \\
\%\end{array}$ & $\begin{array}{c}\text { Su emme } \\
\%\end{array}$ & $\begin{array}{c}V_{p} \\
(\mathrm{~km} / \mathrm{s})\end{array}$ & $\begin{array}{c}\text { SH } \\
\text { Schmidt }\end{array}$ & $\begin{array}{c}I_{s} \\
(M p a)\end{array}$ & $\begin{array}{c}\text { BRT } \\
(M p a)\end{array}$ & $\begin{array}{c}\text { Aşınma } \\
\text { Kaybl } \\
(\mathrm{mm})\end{array}$ & 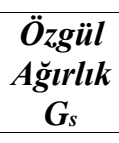 \\
\hline (A) Yeni önerilen taş & 13,51 & 13,64 & 43,78 & 24,07 & 1,588 & 19 & 1,418 & 1,983 & 40,63 & 2,470 \\
\hline (B) Yapıda Mevcut taş 1 & 9,19 & 13,05 & 46,33 & 26,57 & 1,398 & 18 & 1,126 & 1,622 & 52,90 & 2,480 \\
\hline (C) Yapıda Mevcut taş 2 & 9,73 & 12,85 & 47,67 & 26,27 & 1,824 & 14 & 1,538 & 1,174 & 69,7 & 2,510 \\
\hline (D) Yapıda Mevcut taş 3 & 20,74 & 14,81 & 38,67 & 18,72 & 2,154 & 26 & 2,010 & 2,160 & 58,1 & 2,480 \\
\hline (E) Yapıda Mevcut taş 4 & 4,84 & 11,00 & 55,00 & 34,46 & 1,286 & 16 & 1,254 & 0,876 & 64,9 & 2,530 \\
\hline
\end{tabular}

A: Tarihi duvarda tahrip olmuş taşın yerine koyulacak yeni tüf taşı; B, C, D, E: Tarihi yapıda var olan mevcut tüf taşları; UCS: Tek Eksenli Basınç Dayanımı; BHA: Kurı Birim Hacim Ağırlık; Vp: Ultrases Dalga Hızı; SH: Schmidt Sertliği; Is: Nokta Yükleme Dayanım Endeksi BRT: Brazilian Dolaylı Çekme Dayanımı

$\mathrm{Bu}$ grafiklerden de görüldüğü üzere UCS ile BHA, SH, $\mathrm{I}_{\mathrm{s}}, \mathrm{V}_{\mathrm{p}}$ ve BRT arasında pozitif yönde doğru orantı olup UCS artıkça diğer deneysel parametrelerin artığı belirlenmiş ve determinasyon katsayıları sirasiyla $0,9047,0,7794,0,7425,0,7595$ ve 0,8004 olmuştur (Şekil 4).

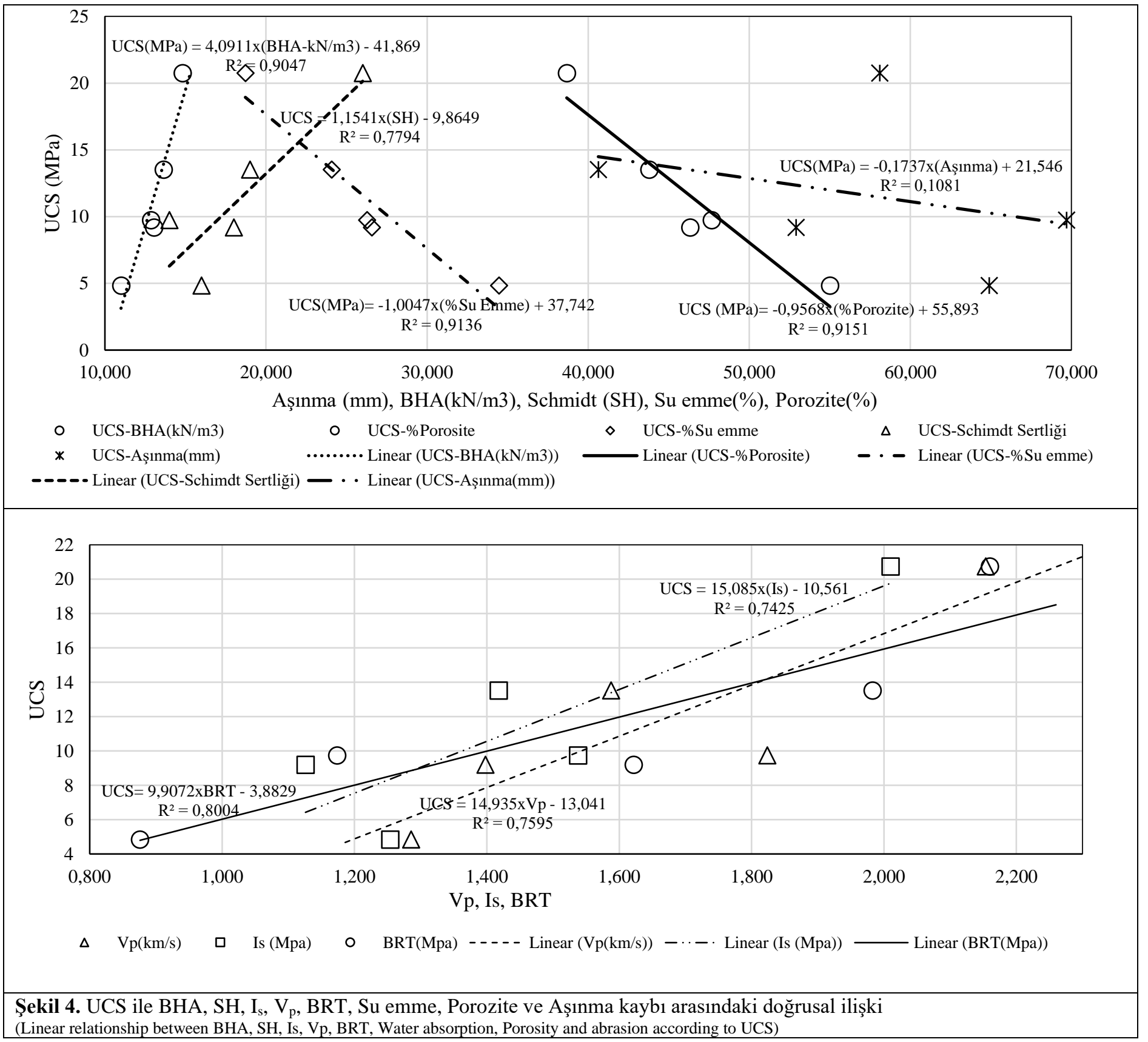


Bunun aksine, UCS ile Su emme, Porozite ve Aşınma kaybı değerleri arasında negatif yönde doğru orantı olup UCS artıkça bu parametrelerin azaldığı belirlenmiştir (Şekil 4). Buradan elde edilen bilgiler doğrultusunda yeni taşın, mevcut taşlara uyumluluğu için basınç dayanımı deneyleri ile elde edilen UCS, Is ve $\mathrm{SH}$ parametrelerinin toplamda $\% 45$, fiziksel özellikleri temsil eden BHA, Gs, Su emme ve Vp parametrelerinin \%35, Çekme dayanımının \%10 ve Aşınma kaybının \%10 etkisi olacağı düşünülmüştür. $\mathrm{Bu}$ çalışmada kullanılan yüzde oranlarının belirlenmesinde ileride yapılacak ulusal veya uluslararası destekli bir proje kapsamında daha detaylı olarak araştırılması yazar tarafından önerilmektedir. Kayseri Sümer Bez Fabrikası restorasyonu kapsamında duvarlarında kullanılan taşların yerine yeni taşın seçimi için önerilen model Tablo 4 de verilmiştir. Burada puanlama hesabı yapılırken pozitif veya negatif yüzde bağıl hata (benzerlik fazlası veya benzerlik eksiği) olarak değerlendirilmiştir. Yüzde bağıl hata hesaplamasının amacı, ölçülen bir değerin gerçek bir değere ne kadar yakın olduğunu ölçmektir. Tablo 4'teki modelde kullanılan puanlama sistemi istatistik biliminde yüzde bağıl hata olarak bilinmektedir. Burada kullanılan yüzde hata (çalışmada benzerlik fazlası veya eksiği olarak kullanılmıştır), mevcut ve yeni taşın deneysel olarak bulunan bir parametresi arasındaki farkın yeni taşın değerine bölünmesi ve yüzde vermek için 100 ile çarpılmasıdır. Hata yüzdesi, pozitif (olumlu benzerlik fazlası) veya negatif (olumsuz benzerlik eksiği) bir değere sahip olabilir. Pozitif ve negatif işaretler, mevcut taşa ait bir parametrik değerin, referans olan yeni taşın bir parametresinden beklenen değerlerin üstüne veya altına düşüp düşmediğini belirlemek için kullanılmıştır (Tablo 4)

Tablo 4. Tarihi Endüstri yapıların korunmasında doğal taşın değiştirilmesi için değerlendirme modeli (Evaluation model for the replacement of natural stone in the preservation of Historic Industrial buildings)

\begin{tabular}{|c|c|c|c|c|c|c|c|}
\hline $\begin{array}{l}\text { Deney } \\
\text { Türü }\end{array}$ & Yapılan Deneyler & \multicolumn{2}{|c|}{\begin{tabular}{|l} 
A \\
(Yeni Taş)
\end{tabular}} & $\begin{array}{l}\text { B } \\
\text { (MevcutTaş1) } \\
\end{array}$ & $\begin{array}{l}\text { C } \\
\text { (Mevcut Taş2) } \\
\end{array}$ & $\begin{array}{l}\text { D } \\
\text { (Mevcut Taş3) } \\
\end{array}$ & \begin{tabular}{|l|} 
E \\
(MevcutTaş4) \\
\end{tabular} \\
\hline \multirow{6}{*}{ 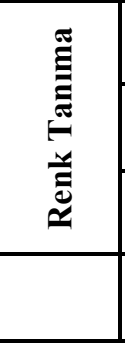 } & $\begin{array}{l}\text { Görsel Renk Durumu ve Taş } \\
\text { Türü }\end{array}$ & \multicolumn{2}{|c|}{ Gri Tüf-Gesi } & Gri Tüf & Gri Tüf & Gri Tüf & Gri Tüf \\
\hline & \multirow{2}{*}{$\begin{array}{c}\text { Aletli Renk Kodları (Red-Green- } \\
\text { Blue) }\end{array}$} & \multicolumn{2}{|c|}{ RGB } & RGB & RGB & RGB & RGB \\
\hline & & \multicolumn{2}{|c|}{$141,132,124$} & $147,141,135$ & $148,132,119$ & $154,145,139$ & $209,209,209$ \\
\hline & $\%$ Benzerlik Puanı & \multicolumn{2}{|c|}{$\% 93$ Kahverengi } & $\begin{array}{c}\% 93 \\
\text { Gri }\end{array}$ & $\% 96$ Kahverengi & $\begin{array}{c}\% 94 \\
\text { Gri }\end{array}$ & $\begin{array}{c}\% 92 \\
\text { Kahverengi }\end{array}$ \\
\hline & \multirow{2}{*}{ YAPILAN DENEYLER } & \multirow{2}{*}{$\begin{array}{c}\% \\
\text { Etkisi }\end{array}$} & Yeni Taş & Mevcut Taş1 & Mevcut Taş2 & Mevcut Taş3 & Mevcut Taş4 \\
\hline & & & $\mathbf{A}$ & B & $\mathbf{C}$ & D & $\mathbf{E}$ \\
\hline \multirow{10}{*}{ 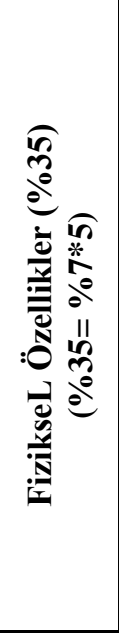 } & Birim Hacim Ağırlık (kN/m³) & \multirow[b]{2}{*}{$7 \%$} & 13,64 & 13,05 & 12,85 & 14,81 & 11 \\
\hline & $\begin{array}{c}X_{1} \% \text { Benzerlik } \\
\text { fazlast veya eksiği }\end{array}$ & & $0 \%$ & $-0,3$ & $-0,4$ & 0,6 & $-1,4$ \\
\hline & Özgül Ă̆grlık, Gs & \multirow[b]{2}{*}{$7 \%$} & 2,47 & 2,48 & 2,51 & 2,48 & 2,53 \\
\hline & $\begin{array}{c}X_{2} \% \text { Benzerlik } \\
\text { fazlasl veya eksiği }\end{array}$ & & 0,0 & 0,0 & 0,1 & 0,0 & 0,2 \\
\hline & Porozite, n (Açık Gözeneklilik) & \multirow[b]{2}{*}{$7 \%$} & $43,78 \%$ & $46,33 \%$ & $47,67 \%$ & $38,67 \%$ & $55 \%$ \\
\hline & $\begin{array}{c}X_{3} \% \text { Benzerlik } \\
\text { fazlasi veya eksiği } \\
\end{array}$ & & 0,0 & $-0,4$ & $-0,6$ & 0,8 & $-1,8$ \\
\hline & Su emme \% & \multirow[b]{2}{*}{$7 \%$} & 24,07 & 26,57 & 26,27 & 18,72 & 34,46 \\
\hline & $\begin{array}{r}X_{4} \% \text { Benzerlik } \\
\text { fazlast veya eksiği }\end{array}$ & & 0,0 & $-0,7$ & $-0,6$ & 1,6 & $-3,0$ \\
\hline & $\mathbf{V}_{\mathbf{p}}(\mathrm{km} / \mathrm{s})$ & \multirow[b]{2}{*}{$7 \%$} & 1,588 & 1,398 & 1,824 & 2,154 & 1,286 \\
\hline & $\begin{array}{c}X_{5} \% \text { Benzerlik } \\
\text { fazlasl veya eksiği }\end{array}$ & & 0,0 & $-0,8$ & 1,0 & 2,5 & $-1,3$ \\
\hline \multirow{6}{*}{ 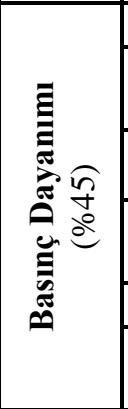 } & Schmidt Çekici değeri & \multirow[b]{2}{*}{$15 \%$} & 19 & 18 & 14 & 26 & 16 \\
\hline & $\begin{array}{c}X_{6} \% \text { Benzerlik } \\
\text { fazlasl veya eksiği } \\
\end{array}$ & & 0,0 & $-0,8$ & $-3,9$ & 5,5 & $-2,4$ \\
\hline & Ort.Nokta Yükleme, Is (MPa) & \multirow{2}{*}{$15 \%$} & 1,418 & 1,126 & 1,538 & 2,01 & 1,254 \\
\hline & $\begin{array}{r}X_{7} \% \text { Benzerlik } \\
\text { fazlast veya eksiğ } i \\
\end{array}$ & & 0,0 & $-3,1$ & 1,3 & 6,3 & $-1,7$ \\
\hline & Ort. UCS (Mpa) & \multirow[b]{2}{*}{$15 \%$} & 13,51 & 9,19 & 9,73 & 20,74 & 4,84 \\
\hline & $\begin{array}{c}X_{8} \% \text { Benzerlik } \\
\text { fazlasl veya eksiği }\end{array}$ & & 0,0 & $-4,8$ & $-4,2$ & 8,0 & $-9,6$ \\
\hline \multirow{2}{*}{ 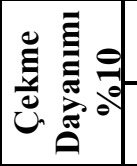 } & $\begin{array}{c}\text { Ort. Brazilian Dolaylı Çekme, } \\
\text { BRT (MPa) } \\
\end{array}$ & \multirow{2}{*}{$10 \%$} & 1,983 & 1,622 & 1,174 & 2,16 & 0,876 \\
\hline & $\begin{array}{c}X_{9} \% \text { Benzerlik } \\
\text { fazlasl veya eksiği } \\
\end{array}$ & & 0,0 & $-1,8$ & $-4,1$ & 0,9 & $-5,6$ \\
\hline \multirow{3}{*}{ 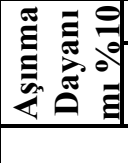 } & Ort. Aşınma Kaybı (mm) & \multirow[b]{2}{*}{$10 \%$} & 40,63 & 52,9 & 69,7 & 58,1 & 64,9 \\
\hline & $\begin{array}{c}X_{10} \% \text { Benzerlik } \\
\text { fazlast veya eksiği } \\
\end{array}$ & & 0,0 & $-3,0$ & $-7,2$ & $-4,3$ & $-6,0$ \\
\hline & TOPLAM PUAN & & 0,0 & $-15,8$ & $-18,6$ & 21,9 & $-32,6$ \\
\hline
\end{tabular}


Mevcut bir taşın, toplam yüzde benzerlik puanı sıfır olması durumunda yeni taşla aynı parametreye sahip olduğu, mevcut taşın toplam puanı pozitif ise yeni taşa göre daha iyi özelliklere sahip olduğu ve toplam puan negatif ise mevcut taşın yeni taşa göre daha olumsuz özelliklere sahip olduğu anlaşılır. Kısaca toplam puanı sıfır olan yeni taş, ondan daha düşük özelliklere sahip (negatif puan olan) mevcut taşların yerine renk uyumu sağlanması koşulu ile kullanılabilecektir. Bunun aksine, yeni taşa göre daha iyi özelliklere sahip (puanı pozitif olan) mevcut taşların yerine yeni taşın kullanılması uygun olmayacaktır. Mevcut taşların, UCS, BRT, Is, SH, Vp değerleri yeni taşın aynı parametresinden daha büyük olursa puana pozitif etki yapmakta ancak Su emme, Porozite ve aşınma kaybı değerleri büyük olursa negatif etki yapmaktadır. Tablo 4'te toplam puana göre en iyi özelliklere sahip taşlar sırasıyla D $(21,9)$, A $(0,0)$, B (-15,8), C ($18,6)$ ve $\mathrm{E}(-32,6)$ dir. Toplam puanlar incelendiğinde, $\mathrm{B}, \mathrm{C}$ ve $\mathrm{E}$ grubu yapıda mevcut taşların yerine, daha iyi fiziksel ve mekanik davranışlara sahip olan A grubu taş yeni taş olarak kullanılabilecektir. Bunun aksine toplam puan1 $+21,9$ olan D grubu mevcut taşların yerine A grubu taşının kullanılması uygun olmayacaktır.

\section{Sonuç (Conclusion)}

Restorasyon açısından tarihi taşların korunması en önemli konudur, ancak binanın korunmasının yeni malzemelerin ve yedek taşların kullanılmasını gerektirdiği durumlar da vardır. $\mathrm{Bu}$ restorasyon çalışmalarında, dayanım özelliği ve görünüm açısından anıtla uyumlu uygun taş kaynakları bulmak zorlu bir görevdir. Bu çalışmada, tarihi endüstri yapısı olan Kayseri Sümer Bez Fabrikası duvarlarında bulunan mevcut taşların ve yerine kullanılacak yeni taşın türlerinin fiziksel, kimyasal ve mekanik özellikleri belirlenerek, kırılan, bozulan deforme olan mevcut taşların yerine yeni taşın seçimi için bir model önerilmiştir.

Tahribatsız deneylerden Ultrases dalga hızının ve Schmidt sertliğinin, yaygın kullanım nedeniyle, tercih edilmesi önerilmiştir. Nokta yükleme, Brazilian dolaylı çekme ve Geniş disk aşınma gibi deneyler, diğer tahribatlı deney yöntemlerine göre daha hızlı ve ekonomik olması yanı sıra zaman ve ekonomiden tasarruf da sağlayan doğal taşların özelliklerinin belirlenmesinde kullanılan modern yöntemlerdir. Önerilen bu modelde, test sonuçlarına göre bu yapıda kullanılan tüf taşlarının Schmidt sertlikleri, Tek eksenli basınç dayanımları, Nokta yükleme basınç dayanımları, Ultrases dalga hızları ile Birim hacim ağırlık değerleri puan hesaplamasında pozitif yönlü olumlu benzerlik yüzdesi sağlarken, Porozite, Su emme ve Aşınma kaybı değerlerinin puana negatif yönlü etki yaptığı belirlenmiştir. Yapılan deney sonucunda, tüf taşlarının basınç dayanımlarının artmasıyla dolaylı çekme dayanımı ve Vp dalga hız değerleri doğru orantılı olarak artmakta, Porozite ve kütlece su emme değerleri ise aynı şekilde doğru orantılı olarak azalmaktadır. Yeni kullanılacak tüf taşının yapıda mevcut taşlara uygun olup olmadığını belirleyen en önemli etkenler olarak Porozite ve $\mathrm{Su}$ emme gibi fiziksel özelliklerin ve basınç dayanımı parametrelerinin olduğu belirlenmiştir. Bunun yanında taşların toplam puan hesaplamasında aşınma kaybı ve dolaylı çekme dayanımının da etki ettiği varsayılmıştır. Sonuç olarak, objektif ölçütlere dayanan yeni bir yaklaşımla, yerine kullanılacak taşı çok daha doğru tahmin etmemize olanak veren ve farklı nitelikteki uyumsuz taşların kullanılma riskini azaltan bir model oluşturulmuştur. Mevcut taşın yerine kullanılacak uyumlu veya daha iyi özelliklere sahip yeni taşı tespit etmede, pratik ve ekonomik yönleri olan bu model ile bilim ve teknolojiye katkı sağlanacağı düşünülmektedir. Ayrıca TÜBİTAK, UNESCO, Avrupa Konseyi, ICOMOS ve ICCROM ile iş birliği yapılarak, tarihi endüstri yapıların dışında diğer eski eserler için de araştırma desteği sağlanarak yeni çalışmalar yapılabileceği ve dünyanın diğer bölgelerindeki tarihi yapılar için de bir model olabileceği planlanmaktadır. Aynı zamanda, malzeme kayıtları olmayan benzer yapılar için geliştirilen bu model ile tarihi yapıyla uyumlu taşın seçilmesinde gereksiz analizlerin yapılması önlenecek, böylece en az müdahale ile tarihi doku korunarak benzer diğer uygulamalar için örnek teşkil edecektir.

\section{Teşekkür (Acknowledgment)}

$\mathrm{Bu}$ araştırmada yapılan arazi ve laboratuvar deneylerimi yaparken Kayseri Üniversitesi İnşaat Programı Öğretim görevlisi Sayın Öğretim Görevlisi Dr. Ergün Yeşilyurt ve Mimari Restorasyon programı Sayın Öğretim Görevlisi Neslihan Babacan'a özellikle teşekkür etmek istiyorum.

\section{Kaynakça (References)}

Aboubacar, M. H., Yavuz, A. B., Tanyu, B. F., Sarı, S. A. (2021). Investigation of the quality of armour stones used in rubble mound breakwater in Güzelbahçe (İzmir), Turkey, Environmental Earth Sciences, 80(11), 1-20.

Acar, M. C., \& Kaya, B. (2020). Models to estimate the elastic modulus of weak rocks based on least square support vector machine, Arabian Journal of Geosciences, 13(14), 1-12.

Aldoasri, M. A., Darwish, S. S., Adam, M. A., Elmarzugi, N. A., \& Ahmed, S. M. (2017). Protecting of marble stone facades of historic buildings using multifunctional $\mathrm{TiO} 2$ nanocoatings, Sustainability, 9(11).

Andriani, G., Walsh, N. (2003). Fabric, porosity and water permeability of calcarenites from Apulia (SE Italy) used as building and ornamental stone, Bulletin of Engineering Geology and the Environment, 62(1),77-84.

Brown, E.T., ISRM (1981). International Society for Rock Mechanics Suggested Methods: Rock Characterization., Testing and monitoring, Oxford.

Çelik, M. Y., \& Sert, M. (2021). An assessment of capillary water absorption changes related to the different salt solutions and their concentrations ratios in the Döğer tuff (Afyonkarahisar-Turkey) used as building stone of cultural heritages, Journal of Building Engineering, 35, 102102.

Del, M. S. T. T., \& Tabrizi, S. K. (2020). A methodological assessment of the importance of physical values in architectural conservation using Shannon entropy method, Journal of Cultural Heritage, 44, 135-151.

Gary, M., Mcafee, R. (1972). Glossary of geology American geological institute. American Geological Institute, Washington, DC, 1972.

Gibeaux, S., Vázquez, P., De Kock, T., Cnudde, V., \& Thomachot-Schneider, C. (2018). Weathering assessment under X-ray tomography of building stones exposed to acid atmospheres at current pollution rate, Construction and Building Materials, 68, 187-198.

Grazzini, A., Fasana, S., Zerbinatti, M., \& Lacidogna, G. (2020). Non-destructive tests for damage evaluation of stone columns: The case study of Sacro Monte in Ghiffa (Italy), Applied Sciences, 10(8), 2673. 
ISRM (1981) Rock characterization, testing and monitoring. In: Brown ET (ed) 1981. International Society for Rock Mechanics (ISRM) Suggested Methods. Pergamon, Oxford, p 211

Kayseri Koruma Kurulu Bölge Müdürlüğü Raporu 12.12.2003.

Kevseroğlu, Ö. (2011) Endüstriyel miras alanlarının kent peyzajına entegrasyonunun değerlendirilmesi: Sümerbank Kayseri Bez Fabrikası Örneği, Doctoral dissertation, Fen Bilimleri Enstitüsü.

Klimek, B., \& Grzegorczyk-Frańczak, M. (2021). Properties of Mortars with Recycled Stone Aggregate for the Reconstruction of Sandstone in Historic Buildings, Sustainability, 13(3), 1386.

Martínez-Martínez, J., Pola, A., García-Sánchez, L., Agustin, G. R., Ocampo, L. O., Vázquez, J. M., \& Robles-Camacho, J. (2018). Building stones used in the architectural heritage of Morelia (México): quarries location, rock durability and stone compatibility in the monument, Environmental earth sciences, 77(5), 1-1.

Michette, M., Viles, H., Vlachou, C., \& Angus, I. (2021). Insitu, non-destructive testing for evaluating the role of pointing mortar in preventive conservation strategies. a case-study on Reigate stone at the Wardrobe Tower, Tower of London, Minerals, 11(4), 345.

Oakeshott, W. (Ed.). (1975). Oxford stone restored: the work of the Oxford Historic Buildings Fund, 1957-1974. (LondonOxford University Press) for the Trustees of the Fund.

Onur, B. (2021). Endüstri kenti Karabük'ün modern mahallesi Yenişehir'de konut tipolojileri. Avrupa Bilim ve Teknoloji Dergisi, (23), 666-677.

Özcan, U., \& Güngör, S. (2019). Geleneksel Türk Evi ile Geleneksel Japon Evi'nin Yapısal Açıdan Karşılaştırılması, Avrupa Bilim ve Teknoloji Dergisi, (16), 646-661.

Přrkryl, R., Török, Á. (2010). Natural stones for monuments: their availability for restoration and evaluation, Geological Society, Special Publications 333, 1-9.

Prrikryl, R. (2007). Understanding the earth scientist's role in the pre-restoration research of monuments: an overview, Geological society london special publications, building stone decay from diagnosis to conservation, 271, Přikryl, R., Smith, B.J. (Eds.), 9-21.

Prrikryl, R., (2006). "New Natural Stone" for the reconstruction of Charles Bridge in Prague, Heritage., Weathering and Conservation, 1, Fort, R., Alvarez de Buergo, M., Gomez-Heras, M., Vazquez-Calvo, C. (Eds.), London, 23-29.

Saba, M., Lizarazo-Marriaga, J., Hernandez-Romero, N. L., \& Quiñones-Bolaños, E. E. (2019). Physico-mechanical characterization of the limestone used in Cartagena walls and a proposal for their restoration process, Construction and Building Materials, 214, 420-429.

Salvatici, T., Calandra, S., Centauro, I., Pecchioni, E., Intrieri, E., \& Garzonio, C. A. (2020). Monitoring and evaluation of sandstone decay adopting non-destructive techniques: Onsite application on building Stones, Heritage, 3(4), 12871301.

Schalkoff, RJ. (1989). Digital image processing and computer vision. New York: John Wiley and Sons, p. 489, 1989.

Serkan, A. (2010). İstanbul tarihi yarımada'daki antik yapılarda ve anıtlarda kullanılan doğal taşların özellikleri ve korunmuşluk durumları, Restorasyon ve Konservasyon Çalışmalarl Dergisi, (6), 31-42.
Sobotka, A., Linczowski, K., \& Radziejowska, A. (2021). Substitution of Material Solutions in the Operating Phase of a Building, Applied Sciences, 11(6), 2812.

Sousa, L. M. (2014). Petrophysical properties and durability of granites employed as building stone: a comprehensive evaluation, Bulletin of Engineering Geology and the Environment, 73(2), 569-588.

Şen E., Kürkcüoğlu B., Aydar E., Gourgaud A., Vincent, P.M. (2003). Volcanological evolution of mount erciyes stratovolcano and origin of the Valibaba Tepe ignimbrite (Central Anatolia, Turkey)., Journal of Volcanology and Geothermal Research 125:225-246.

Tanrıverdi, ş., \& Çelik, T. (2021). Farklı dolgu malzemeleri ile sabitlenen zıvanaların yığma taş blokların kayma dayanımına etkisi, Avrupa Bilim ve Teknoloji Dergisi, (25), 347-354.

Török, Á., \& Přikryl, R. (2010) Current methods and future trends in testing, durability analyses and provenance studies of natural stones used in historical monuments, Engineering Geology, 115(3-4), 139-142.

TS 699 (2009) Methods of testing for natural building stones. Turkish Standards Institution, Ankara

Winkler, E. M. (1997). Color and color stability of stone. In Stone in Architecture (pp. 91-110). Springer, Berlin, Heidelberg. 